REVIEW

This paper is dedicated to the $70^{\text {th }}$ anniversary of the founding of Physiologia Bohemoslovaca (currently Physiological Research)

\title{
Antibody-Mediated Rejection of Renal Allografts: Diagnostic Pitfalls and Challenges
}

\author{
Marek NOVOTNY ${ }^{1,4}$, Martin KMENT ${ }^{2}$, Ondrej VIKLICKY ${ }^{1,3,4}$ \\ ${ }^{1}$ Department of Nephrology, Institute for Clinical and Experimental Medicine, Prague, Czech \\ Republic, ${ }^{2}$ Department of Clinical and Transplant Pathology, Institute for Clinical and Experimental \\ Medicine, Prague, Czech Republic, ${ }^{3}$ Transplant Laboratory, Institute for Clinical and Experimental \\ Medicine, Prague, Czech Republic, ${ }^{4} 1$ st Medical Faculty, Charles University, Prague, Czech \\ Republic
}

Received September 2, 2021

Accepted November 2, 2021

\section{Summary}

Antibody-mediated rejection (ABMR) is a major obstacle to the long-term success in kidney transplantation. Diagnosis of ABMR is determined according to the internationally recognized Banff criteria. However, a significant proportion of patients does not meet all the defined criteria, and the outcome of such cases remains poorly understood. The histology of ABMR frequently lacks sensitivity and specificity. More importantly, mixed forms of ABMR and $T$ cell-mediated rejection as well as findings of nonspecific injury are common in clinical settings. Donor-specific anti-HLA antibodies (DSA) are detectable only in half of the ABMR cases by histology. Prognostic role of non-HLA antibodies against various endothelial proteins has been discussed. Antibody independent NK cell activation reflecting killer-cells' inhibitory receptor incompatibility is suggested in microvascular inflammation in DSA negative patients. Molecular assessment of ABMR has been prioritized to overcome high interobserver variability and improve diagnostics in mixed forms of rejections and in DSA negative cases. Finally, donor-derived cell-free DNA detected in a recipient's peripheral blood sample has been proposed as a noninvasive marker for diagnosis of graft rejection, and thus might serve as a liquid biopsy in the near future. Despite all achievements, diagnosing ABMR in kidney allografts remains to be a challenge in a significant number of cases.

\section{Key words}

Kidney transplantation - Antibody-mediated rejection - Donorspecific antibodies • Banff classification • Rejection diagnostics

\section{Corresponding author}

Ondrej Viklicky, Transplant Center, Dept. of Nephrology, Institute for Clinical and Experimental Medicine, Vídeňská 1958, 14021 Prague, Czech Republic. E-mail: ondrej.viklicky@ikem.cz

\section{Introduction}

Kidney transplantation represents a treatment of choice for end-stage renal disease (ESRD) with a significantly higher graft survival rate and lower treatment costs compared to hemodialysis (Kramer et al. 2020). Over the past two decades, short-term graft survival has significantly improved due to advances in immunosuppressive regimens, but long-term kidney graft survival has remained largely unchanged. Apart from recurrence of the original disease in the graft, a major cause of kidney transplant failure is chronic antibodymediated rejection (ABMR) (Parajuli et al. 2019). In this review, we aim to summarize some of the recent findings in the field of ABMR pathology and diagnostics.

\section{Pathogenesis of antibody-mediated rejection}

Recently, it has been reported that a number of kidney transplant waitlist patients show detectable levels of anti-HLA antibodies due to previous pregnancy, blood transfusion, prior transplantation or as a result of heterologous immunity (Mumford et al. 2021). Antibody- 
mediated rejection is the consequence of an interaction between the recipient's antibodies and antigens localized on donor endothelium. These antibodies are either donorspecific anti-HLA antibodies, or non-HLA antiendothelial cell antibodies (Fichtner et al. 2021).

Phenotypes of ABMR have been conventionally defined as hyperacute, acute and chronic. Donor-specific antibodies may be preformed or develop de-novo after transplantation. ABMR may be caused by donor-specific antibodies' direct cytotoxic effect, complement activation or complement independent recruitment of leukocytes (Garg et al. 2017).

Hyperacute rejection occurs within hours after reperfusion because of the presence of high levels of preformed complement fixing antibodies. This worst case scenario was frequently observed at pioneer times and at present it represents a rare event resulting from a falsenegative result of complement-dependent cytotoxicity crossmatch (CDC) test performed just before surgery. Aside from such a rare complication, many transplantations are performed despite a minor HLA barrier when DSA levels are too low to cause positivity of CDC or flow cytometric crossmatch tests (Amrouche et al. 2017). Moreover, memory B-cells may play a role in antibody development shortly after transplantation as well (Luque et al. 2019).

DSA may also occur de novo later after transplantation, mostly as a result of inadequate immunosuppression (Mohammed et al. 2021). Both the preformed and the de novo DSA are associated with the development of chronic active antibody-mediated rejection. This finding is characterized by basal membrane multilayering, progressive scarring and fibrosis, leading to glomerular loss, proteinuria and graft dysfunction (Zhang et al. 2018).

Table 1. Evolution of ABMR diagnostic criteria during Banff meetings where significant changes were involved

1991 Hyperacute rejection - rejection presumed to be due to preformed antibody

1997 Antibody-mediated rejection - rejection demonstrated to be due, at least in part, to anti-donor antibody

A. Immediate (hyperacute)

B. Delayed (accelerated acute)

2001 Defined 3 grades of ABMR

I. ATN-like (minimal inflammation), $\mathrm{C} 4 \mathrm{~d}+$

II. Capillary-margination and/or thromboses, $\mathrm{C} 4 \mathrm{~d}+$

III. Arterial - v3, C4d+

Documented DSA

Suspicious for ABMR when DSA not detected

2013 Acute/active ABMR, all three features must be present for diagnosis

I. Histologic evidence of acute tissue injury - microvascular inflammation, intimal arteritis, thrombotic microangiopathy, acute tubular injury

II. Evidence of recent antibody interaction with endothelium

a. C4d staining in peritubular capillaries

b. At least moderate microvascular inflammation

c. Increased expression of transcripts indicative of endothelial injury

III. Serologic evidence of DSAs

2015 Suspicious for ABMR when criterion 2 is missing in presence of DSA or criteria 1 and 2 are fulfilled but DSA are missing

2017 Alternatives for DSA when missing: C4d positivity, molecular markers of ABMR.

Term acute was excluded from the classification

The approved nomenclature:

Active ABMR

Chronic active ABMR

Chronic ABMR

Term suspicious for ABMR excluded from the classification 

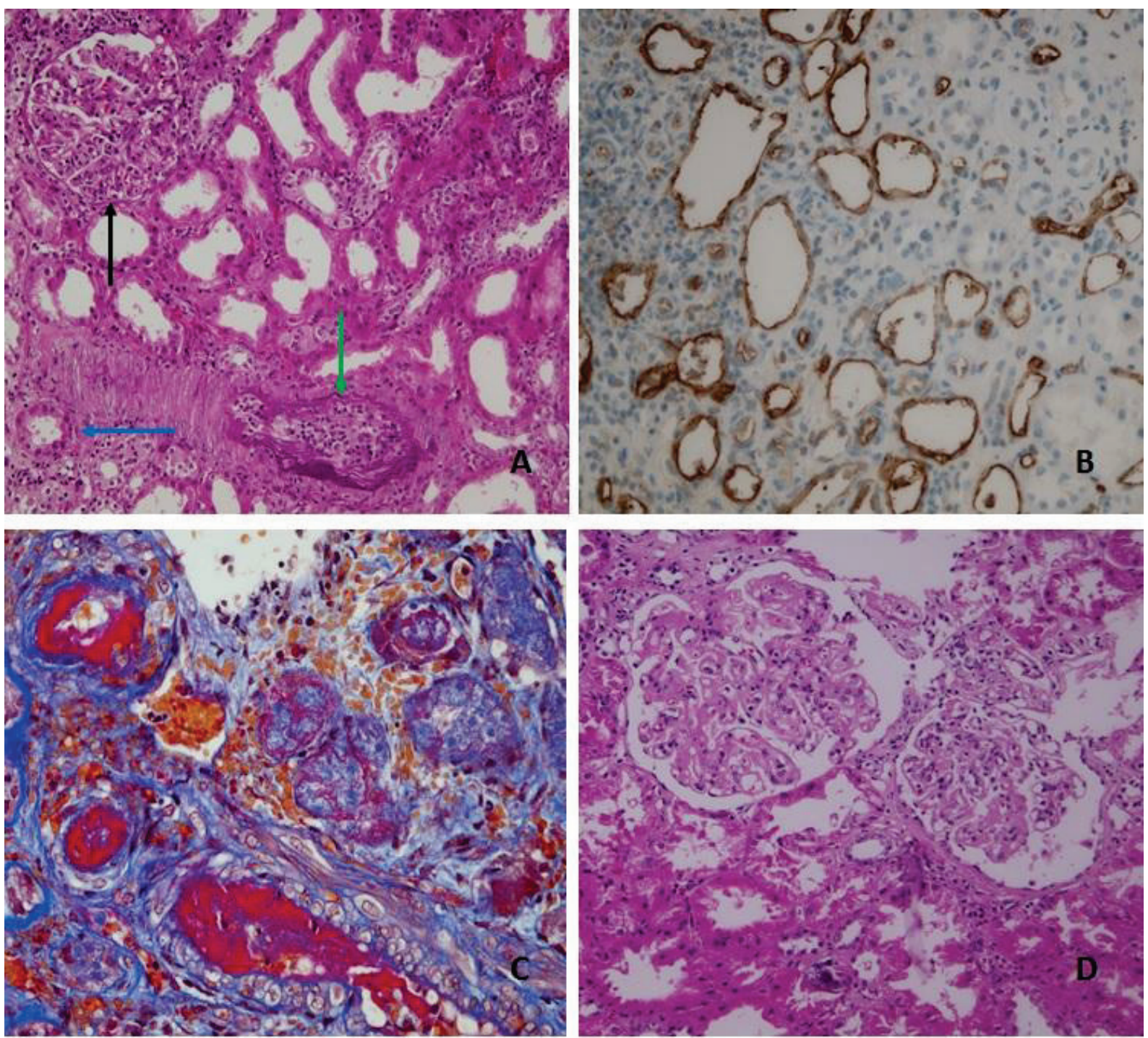

Fig. 1. A Histologic features of active antibody-mediated rejection, glomerulitis (g3) (black arrow), peritubullar capillaritis (ptc2) (blue arrow), intimal arteritis (v2) (green arrow). B C4d staining in peritubullar capillaries (immunohistohemistry). C Fibrinoid necrosis of muscular arteries (v3) (red color) a histologic feature of both antibody-mediated rejection or acute cellular rejection grade III. D Transplant glomerulopathy a hallmark of chronic antibody-mediated rejection.

Over the past 5 years, another mechanism of IgG independent inflammatory cell recruitment and complement independent endothelial damage has been described and will be discussed later (Charreau et al. 2021).

\section{Classification of kidney allograft rejection}

The most commonly used rejection classification is that according to the Banff Working Group (Schinstock et al. 2021). The group started meeting in 1991 in Banff, Canada, and originally consisted of pathologists, nephrologists and surgeons with expertise in the field of organ transplantation, and their goal was to define the clinical and histological criteria of kidney transplant rejection (Solez et al. 1993). The internationally recognized diagnostic standard used at present, the Banff classification, is based on the discussions that were led at the biennial meetings (Table 1). The Banff classification is used not only in the field of kidney transplantation, but in the field of other solid organ transplantation as well, and the expert panel has also adopted immunologic, genetic and transcriptomic data (Loupy et al. 2020).

The Banff classification introduced a numerical grading system from 0 to 3 (mild to severe), indicating the level of inflammation in glomerular, interstitial, tubular and vascular compartments. Chronic lesions are defined by the presence of fibrosis or by the multilayering of basal membranes (Fig. 1).

Scores for each compartment are named and 
abbreviated as glomerulitis (g), peritubular capillaritis (ptc), transplant glomerulopathy (cg), intimal arteritis (v), interstitial inflammation (i), tubulitis ( $\mathrm{t}$ ), mesangial matrix increase (mm), vascular intimal fibrosis (cv), arteriolar hyaline thickening (ah), interstitial fibrosis (ci) or tubular atrophy (ct). Immunofluorescence or immunehistochemical detection of covalently bound $\mathrm{C} 4 \mathrm{~d}$ complement component in peritubular capillaries was identified as a relatively durable marker of complement activation associated with donor-specific antibodies and antibody-mediated rejection, and was implemented to the Banff classification as a diagnostic criterion of antibody and endothelium interaction (Racusen et al. 2003).

Initially, the diagnostic criteria for TCMR, characterized by tubulointerstitial inflammation and intimal arteritis, have been described more extensively than the diagnostic criteria of ABMR due to high incidence of TCMR during year-1 post-transplant and a potential of early graft loss due to TCMR. Widespread use of calcineurin inhibitors (CNI), targeting $\mathrm{T}$ lymphocytes specifically, dramatically improved shortterm graft survival and made it possible to treat TCMR. Conversely, ABMR has become a major obstacle to further improvement of long-term graft survival, and the aim shifted to the identification of ABMR diagnostic criteria, and to the prognosis of its different phenotypes (Djamali et al. 2014).

According to the most recent Banff classification update, the diagnostic criteria of active ABMR are divided into three categories and are considered fulfilled if at least one criterion from each category is met (Loupy et al. 2020).

1) Histologic evidence of acute tissue injury - presence of microvascular inflammation (glomerulitis, peritubular capillaritis), intimal arteritis, thrombotic microangiopathy, acute tubular necrosis in absence of other apparent cause

2) Evidence of current/recent antibody interaction with vascular endothelium
a. $\quad \mathrm{C} 4 \mathrm{~d}$ staining in peritubular capillaries detected by IF or IHC
b. At least moderate microvascular inflammation
c. Increased expression of gene transcripts associated with ABMR

3) Serological evidence of circulating donor-specific antibodies to HLA or other antigens. C4d staining or expression of validated transcripts may substitute for DSA. Testing for non-HLA antibodies if the result of HLA antibody testing indicates negative is advised.
Chronic active ABMR involves the presence of transplant glomerulopathy in addition to the above listed criteria. Chronic (inactive) ABMR is observed in patients with transplant glomerulopathy in the absence of a recent antibody - endothelium interaction.

\section{Challenges in ABMR diagnosis}

The Banff classification strictly categorizes histologic changes as either TCMR (tubulointerstitial inflammation, TI) or ABMR (microvascular inflammation, MVI). A category of mixed rejection is not officially recognized, even though a significant number of patients present simultaneous TI and MVI. A mixed rejection category is, however, used in literature in an attempt to recognize and characterize these cases. The incidence of mix rejection varies between $6-96 \%$ of cases, which is indicative of the lack of consensus, and the need for a more complex terminology (Hara et al. 2018).

Pure rejection phenotypes are relatively rarely observed in clinical settings beyond the first year posttransplant. If a patient meets the criteria for histologic ABMR diagnosis (with or without concomitant TI), they should be assessed with caution because they could potentially have a worse outcome from ABMR compared to TCMR. Cases with mixed rejection phenotype are often associated with nonadherence and with an increased risk of resistance even to antibodies targeting treatment (Loupy et al. 2017).

Intimal arteritis (or v-lesion, vascular rejection) represents an ambiguous finding between histologic criteria indicating acute tissue injury. V-lesion is characterized by subendothelial inflammation of muscular arteries and is the only histologic criterion with a Banff score placed into both categories of the diagnostic criteria. Originally, intimal arteritis was regarded as a diagnostic feature of TCMR, but further investigation of steroid resistance and worse graft survival observed in some patients revealed the association of intimal arteritis and DSA, and was therefore also included as an ABMR diagnostic criterion (Lefaucheur et al. 2013). Antibodymediated vascular rejection is associated with the highest incidence of graft loss, exceeding other rejection phenotypes (Novotny et al. 2018). On the other hand, intimal arteritis in early posttransplant biopsies may also be caused by reperfusion injury with likely an insignificant prognostic impact (Wohlfahrtova et al. 2018). 
Diagnostic criteria of ABMR also involve changes that may indicate unspecific damage. Acute tubular necrosis (ATN) following kidney transplantation is frequently observed in early posttransplant biopsies because of ischemic-reperfusion injury (Lechevallier et al. 1998). ATN in presence of diffuse C4d positivity has been classified as ATN-like ABMR since 2001 (Racusen et al. 2003).

Thrombotic microangiopathy (TMA) absent an apparent cause represents another hard to distinguish diagnostic feature of ABMR. TMA has been reported as a drug induced complication related to CNI use soon after their widespread implementation (Remuzzi et al. 1989). Other diagnoses to be excluded are the recurrence of hemolytic-uremic syndrome or parainfectious disorders (HCV) (Goplani et al. 2008).

Recurrence of a patient's original kidney disease may imitate both acute and chronic rejection on a histologic level.

Kidney graft may be affected by the same spectrum of inflammatory diseases as the patient's native kidneys, such as drug- or infection-induced tubulointerstitial nephritis (De Souza et al. 2021).

Determining the meaning of an inflammatory lesion in a kidney graft parenchyma is a question often posed to an interdisciplinary diagnostic seminar.

\section{Evidence of antibody interaction with vascular endothelium}

Histologic evidence of acute tissue injury alone is not a specific enough finding for ABMR diagnosis. The evidence of antibody interaction with the vascular endothelium is predicated on the presence of microvascular inflammation of at least moderate intensity (sum of Banff scores for $g$ and ptc at least 2). C4d staining in peritubular capillaries serves as a relatively durable marker of complement activation as $\mathrm{C} 4 \mathrm{~d}$ fragment binds covalently to endothelial cells. At the Banff 2001 conference, C4d has been acknowledged as a specific marker of DSA presence and its association with worse graft prognosis was revealed (Racusen et al. 2003). One of the key studies presented at the conference indicated a $95 \%$ correlation of C4d to DSA, and a worse prognosis in $\mathrm{C} 4 \mathrm{~d}$ positive patients even in the absence of DSA (Mauiyyedi et al. 2002). A different study presented at the conference pointed at the fact that $\mathrm{C} 4 \mathrm{~d}$ may be specific for DSA (93\%), but insensitive (30\%). In histology, C4d was confirmed as an independent predictor of graft failure and was declared an essential marker for establishing a definitive ABMR diagnosis (Regele et al. 2001). C4d negative biopsies with histologic marks of ABMR even with detected DSA were classified as suspicious for ABMR.

At the Banff 2011 conference, there was ageneral consensus that some of the $\mathrm{C} 4 \mathrm{~d}$ negative cases will need to be classified as definitive ABMR. Some of the participants raised concern about a potential increase in the number of ABMR cases, which would result in a larger number of patients requiring intensive treatment, and expressed the need for a more precise definition of the criteria thresholds (Mengel et al. 2012). At the 2013 Banff conference, C4d negative ABMR was officially introduced into the classification and the previously necessary $\mathrm{C} 4 \mathrm{~d}$ positive result has been replaced by up to date valid criterion 2 (evidence of antibody interaction with vascular endothelium which contains at least moderate MVI, C4d positivity and/or increased expression of gene transcripts associated with ABMR) (Haas et al. 2014). ABMR without evidence of DSA was accepted into the classification at the 2017 Banff conference, and $\mathrm{C} 4 \mathrm{~d}$ staining became a surrogate marker compelling enough to establish ABMR diagnosis along with MVI (Haas et al. 2018).

Independent prognostic value of $\mathrm{C} 4 \mathrm{~d}$ in absence of DSA was later questioned by Senev, who published data on the prevalence and impact of histologic ABMR which he had researched on a large patient sample $(\mathrm{N}=208)$, suggesting that $\mathrm{C} 4 \mathrm{~d}$ staining in absence of DSA represents a significantly lower risk than in the presence of DSA (HR in comparison with no rejection 1.09 for DSA-C4d+ and 2,67 for DSA+) (Senev et al. 2019).

When C4d staining became available, C4d positivity without any tissue inflammation was observed. This phenomenon is called accommodation and is commonly observed in $\mathrm{AB} 0$ incompatible kidney transplants, where low titers of hemagglutinins lead to regulated complement activation that does not cause cellular lysis (Hruba et al. 2019).

There is increasing evidence about the meaning of $\mathrm{C} 4 \mathrm{~d}$ positivity in the absence of rejection in $\mathrm{AB} 0$ compatible kidney transplants. Dominy et al. explored whether there was a connection between $\mathrm{C} 4 \mathrm{~d}$ positive biopsies without evidence of rejection and ABMR-related transcripts. The results showed that in a majority $(\mathrm{N}=46)$ of these samples, the ABMR transcript score was low, and in patients with a high ABMR transcript score $(\mathrm{N}=7)$ a histologic ABMR occurred in 5 patients within one year 
post-transplant compared to just 2 patients from the first group (Dominy et al. 2018).

Positive staining for $\mathrm{C} 4 \mathrm{~d}$ was once considered an independent predictor of ABMR and graft failure. More recently, its insufficient sensitivity was proven and in the absence of DSA, its independent prognostic value is considered questionable.

\section{Serologic evidence of circulating donor- specific antibodies}

Concerns about potential harmful antibodies have been accompanying organ transplantation hand in hand since the program was initiated. CDC crossmatch represents one of the most important scientific advances in kidney transplantation of the $20^{\text {th }}$ century due to its hyperacute and early acute ABMR incidence reduction capability. CDC is, from the technical standpoint, a relatively simple method. Donor's isolated lymphocytes are cultivated with the recipient's serum and a rabbit complement, which leads to cellular death and lysis if complement fixing antibodies are present, with an optical read-out after a defined time period (Bray et al. 2011). CDC can detect the presence of high amounts of complement activating antibodies, but unfortunately it does not factor in the influence of lower antibody titers or those that do not activate the complement, but still might be clinically significant. IgM and IgG antibodies can both trigger cellular lysis in conventional CDC settings, and if the recipient's serum contains autoantibodies, they can cause the $\mathrm{CDC}$ to give a false positive result.

Panel reactive antibodies (PRA) test measuring a relative sensitization of waitlisted patients is based on the principle of CDC assay. Lymphocytes derived from a representative donor pool are cultivated with the recipient's serum in separate pits, and the proportion of samples displaying cellular lysis represents a level of patient's sensitization.

Because the $\mathrm{CDC}$ has a limited ability to eliminate early acute ABMR, methods with a higher sensitivity have been investigated. Flow cytometric crossmatch technique (FCXM), which examines the binding of the recipient's serum IgG antibodies to the donor's lymphocytes, was invented. FCXM allows for a higher standardization, separate $\mathrm{T}$ and $\mathrm{B}$ lymphocyte evaluation possibly identifying class II antibodies and, most importantly, it is a useful tool in revealing a potential risk of ABMR due to its higher sensitivity (Nelson et al. 1996).
CDC and FCXM both depend on availability of viable donor lymphocytes, which limits possible repetitions and reduces time after transplantation when examinations can be performed.

The next great advantage in the field of antiHLA detection are solid phase assays, which utilize purified HLA proteins as targets. Compared to FCXM, earlier used ELISA did not demonstrate an increased sensitivity to anti-HLA (Buelow et al. 1995). Multiplex bead-based method $\left(\right.$ Lumine $\left.^{\mathrm{R}}\right)$, separating microparticles each carrying one type of recombinant HLA protein on its surface, has become the widespread platform for high-sensitive serum anti-HLA evaluation. To this day, the majority of transplant centers in developed countries provide Luminex serum analysis both to pre-transplant patients, as well as to patients with a suspected ABMR as an essential part of examination (Schinstock et al. 2021). It was not possible to establish a definitive diagnosis of ABMR without DSA detection until 2017, when raising concerns about DSA negative patients with histologic ABMR lead to the definition of surrogate markers in $\mathrm{C} 4 \mathrm{~d}$ and transcriptome evaluation (Haas et al. 2018).

The ability to detect antibodies using highly sensitive assays has brought about a new set of challenges to physicians' decision making. Detected antibodies do not behave the same way biologically, and their presence does not necessarily imply rejection. IgG subclasses can trigger the complement and recruit effector cells differently (Zhang et al. 2018). IgG3 specifically has been identified as associated with severe ABMR, C4d deposition and poorer graft outcome (Pernin et al. 2020). Complement binding antibodies have been proven to increase the risk of graft failure almost 5-fold compared to non-binding DSA (Loupy et al. 2013).

The number of sensitized patients on waiting lists is rising, and the longer they receive dialysis, the more their health condition deteriorates. Because of these circumstances, physicians are forced to allow transplantations despite the barrier of anti-HLA antibodies. One possible solution is desensitization, an attempt to lower the DSA titers with antibodies-targeting treatment. Another solution is avoiding the mismatch by kidney pair donation, or attempting to extend the pool of potential donors (international allocation).

A successful approach realized in an acceptable mismatch program. The concept of acceptable mismatch was originally based on a stepwise serum evaluation of the recipients against the lymphocytes of blood donors 
with exactly one HLA mismatch in an attempt to identify combinations with negative CDC assays. The technique was improved with the ability to prepare single antigen cell lines that express solely one HLA antigen.

Epitope analysis of HLA molecules has provided another pathophysiological insight into the antibodyantigen interaction. Each HLA molecule consists of several epitopes. Even when two individuals differ in a conventional HLA typing, it is possible that these two do not differ in the epitope set, and therefore recipient HLA antibodies will not react (Heidt et al. 2018). This high-resolution epitope-based HLA characterization is the basis for HLA matchmaker used in the acceptable mismatch program.

\section{Histologic ABMR with undetectable DSA}

In a considerable number of patients with histological features of ABMR, physicians fail to detect anti-HLA DSA. In his cohort study including 208 patients with histological features of ABMR, Senev identified 125 DSA negative cases (Senev et al. 2019). Previously, the Banff classification allowed the term "suspected for ABMR" for these cases, which was excluded from the criteria in 2017. The term "histologic ABMR" is used in literature for cases meeting the first two Banff criteria without evidence of detectable antibodies.

The Banff classification accepts the fact that there are patients with ABMR histology, but undetectable DSA. This situation should not be interpreted as a recognition of "antibodies negative" ABMR, rather that there are concerns about the ability to reliably detect all harmful antibodies (Haas et al. 2018). We will discuss the possible pathophysiology of histologic ABMR without DSA later on.

\section{Non-HLA antibodies}

A possible explanation of non-HLA antibody formation might be that HLA mismatch is not the exclusive cause of donor and recipient incompatibility. Minor histocompatibility antigens (mHA), the number of transmembrane proteins, can vary even in HLA identical individuals. Recently, our ability to identify a mismatch in mHA has improved. Non-synonymous single nucleotide polymorphisms of transmembrane proteins were evaluated by genome wide genetic analysis in a cohort of 1500 transplanted patients. Non-HLA donor- specific antibodies were identified using mass spectroscopy in patients with genetically revealed mismatch in mHA leading to higher risk of histologic chronic ABMR (Reindl-Schwaighofer et al. 2019).

Researchers have been searching for potentially harmful non-HLA antibodies against specific endothelial targets for decades. Antibodies directed toward angiotensin II type I receptor (AT1R) have been the most frequently reported antibodies associated with rejection. Originally, the association of AT1R antibodies with vascular rejection was described by Dragun, who conducted a study involving 33 patients with vascular rejection, and identified 16 anti-HLA DSA negative patients with AT1R antibodies (Dragun et al. 2005). In up to date results of a prospective two-center study involving 1845 patients, the presence of AT1R antibodies was revealed in $20 \%$ patients, and in $7 \%$ along with DSA. Adjusted HR of allograft loss was 1.49 for AT1R alone, and 2.26 for combination of DSA and AT1R antibodies (Lefaucheur et al. 2019).

Independent effect of non-HLA antibodies is still a matter of discussion. Serum analyses of 38 DSA negative patients with early ABMR by endothelial crossmatch were performed by Delville, along with a test for AT1R and endothelin-1 type A antibodies (Delville et al. 2019). Specific independent association of any type of antibodies with MVI was not confirmed, but overall serum reactivity by endothelial crossmatch was observed in patients with non-HLA antibodies.

Whether non-HLA antibodies represent a potential therapeutic target also remains an unanswered question. It seems that the prognosis of kidney allografts in DSA negative patients, even those with histologic ABMR finding, is significantly better than in patients with DSA positive ABMR (10 year graft survival was $76 \%$ in histologic ABMR but DSA negative patients, and $54 \%$ in ABMR DSA positive patients) (Senev et al. 2019). Indication of costly antibodies-targeting treatment with potentially severe side effects remains controversial, even in cases with a high degree of suspicion for the presence of non-HLA antibodies.

\section{Missing self concept in solid organ transplantations}

The notion that microvascular inflammation is caused exclusively by an antibodies-endothelium interaction is being questioned by increasing numbers of patients, in whom no harmful antibodies have been 
detected even by highly sensitive assays. Other pathophysiological mechanisms elucidating the presence of MVI have been investigated. A theory of antibody independent activation of the recipient's NK cells after an interaction with the donor endothelium was postulated in the field of organ transplantation.

Direct NK cell activation on the endothelial surface was originally thought to be a response to lowered expression of HLA-I on the cellular surface (Ohlen et al. 1989). NK-cells are thus able to respond to tumor cells or cells infected by viruses. Another theory discussing the direct activation of NK-cells is centered around the discovery of inhibitory killer cell immunoglobulin-like receptors (KIRs) (Moretta et al. 1990). In other words, both the presence of the appropriate HLA-I pattern, and the inhibition of NK cells by KIRs, lead to prevention of their activation against self-structures, and the lack of HLA-I or KIRs signal may therefore lead to "missing self", and trigger the NK cells.

Koenig et al. presented the influence of interindividual genetic heterogeneity in KIRs between a donor and a recipient as a possible cause of NK cell MVI in the absence of DSA in approximately $2 / 3$ of patients (Koenig et al. 2019). For transplant purposes, it is important that HLA a KIRs heterogeneity is inherited independently (HLA molecules are coded on chromosome 6, KIRs on chromosome 19), therefore HLA compatible individuals may have broad KIRs heterogeneity. In their recently published clinical study, Koenig showed that NK cell activation, triggered by the missing self, may contribute to the intensity of inflammation along with DSA, and lead to a higher risk of graft loss (HR 3,6, p=0.04, multivariate analysis) (Koenig et al. 2021).

\section{Assessment of gene transcripts associated with ABMR}

The evaluation of transcriptomes obtained from biopsy samples of transplanted kidneys in an experimental setting is being developed since the 1990s (Lipman et al. 1992). At first, researchers were focusing on several transcripts that were possibly associated with the regulation of inflammatory processes, and correlated their findings with conventional histology to reveal possible rejection specific intragraft transcriptome changes. During that time, the PCR method and the computer capacity have both improved, and parallel evaluations of tens of thousands of transcripts in microarray settings became possible.

Transcriptome analysis was included into the Banff classification in 2013, although at that time, it served rather as a proposal for further research than a fully developed diagnostic tool (Mengel et al. 2020). The first commercially available diagnostic system based on transcriptome analysis of biopsy samples is the Molecular Microscope (MMDx, One-Lambda). The MMDx was being developed for over a decade by comparing analyses of mRNA from biopsy samples of 703 patients with their histological diagnoses during the INTERCOM study (Halloran et al. 2013). Microarray based ABMR score showed $85 \%$ agreement with conventional diagnoses, and provided more accuracy for the prediction of graft dysfunction and failure. The MMDx system uses machine learning algorithms and the reference dataset is still expanding. Later published INTERCOMEX study prospectively involved another 538 patients' samples, both full-core biopsies, or parts of samples, and the evaluation was performed in real time within 29 hours of delivery. Consensus between conventional diagnosis and MMDx reached $77 \%$ in both ABMR and TCMR, and clinicians, aware of all patients results, agreed more $(87 \%)$ with the MMDx diagnosis than with the conventional diagnosis $(80 \%)$ (Halloran et al. 2017). The MMDx system demonstrated the ability to establish a diagnosis with a relatively high accuracy from small tissue samples, or samples containing only medulla (Madill-Thomsen et al. 2017).

Biolaboratories involved in the project used standardized microarrays and sample processing to eliminate result variability. The MMDx was able to demonstrate high reproducibility of the molecular scores in comparison with interobserver variability of common histology readings.

The other novel microarray based on a diagnostic system was introduced by NanoString technologies (Seatle, WA). NanoString does not use a separate biopsy core or a part of a core placed into the RNA later like the MMDx, but performs an analysis on a sample separated from formalin-fixed, paraffin embedded (FFPE) biopsies. A thin layer of tissue from a fixed sample is separated by a microtome. That makes it possible to perform microarray analyses on stored samples originally not meant for transcriptomic evaluation, and compare the exact same part of tissue that was read by an optical microscope. Because RNA is vulnerable to damage in conventional processing, the NanoString technology supposedly requires as little as 
$1 \mathrm{ng}$ of RNA per input is enough for evaluation (Goytain et al. 2020).

Despite all the progress, there are some limitations to Molecular Microscope or transcriptomic examinations in general. MMDx cannot diagnose glomerular diseases based exclusively on histology, like recurrent glomerulonephiritides and diabetic nephropathy. Polyoma BK virus presence also lowers the reliability of the MMDx score (Madill-Thomsen et al. 2020).

Cases of histological ABMR in absence of DSA represent a diagnostic challenge even for transcriptomic evaluation. Transcriptome of biopsy samples from patients with histologic ABMR was assessed with no differences revealed between DSA positive and negative cases, even when the prognosis of both groups was distinct (ABMRh DSA+ HR 7.2, ABMRh DSA- HR 2.3) (Callemeyn et al. 2020).

\section{Rejection biomarkers}

Efforts to reliably diagnose graft rejection with minimal invasive examinations accompany transplant medicine from the beginning. Changes in renal function measured by serum creatinine and glomerular damage indicated by proteinuria are relatively late markers of allograft damage.

Changes in cytokine levels have been described in patients with rejection. Pro-inflammatory cytokines have been associated with rejection and graft loss and anti-inflammatory cytokines may contribute to the regulation of rejection (De Menezes et al. 2013). On the other hand, serum cytokine levels are easily universally affected by infections and autoimmune diseases, and thus lack specificity for rejection.

Novel promising biomarkers specific for allograft damage may be represented by donor-derived cell-free DNA (dd-cfDNA). Increased load of donor's DNA detectable in the recipient's bloodstream means the cellular damage of the transplanted organ. To reach predictive value for rejection, it is necessary to perform repeated measurements of dd-cfDNA as there is a large inter- and intraindividual variability depending on the type of the donor and time after transplantation. Repeated transplants, transplants from extended criteria donors, dual transplants and higher immunologic risk might be associated with higher dd-cfDNA (Anand et al. 2021). Gupta presented the study in which a correlation of predictive value of dd-cfDNA in comparison with standard of care histologic assessment and MMDx was performed (Gupta et al. 2021). Predictive value of dd-cfDNA for rejection correlated slightly better with the MMDx (AUC 0.8), than with conventional histology (AUC 0.75).

Urinary biomarkers are potentially a very attractive field of research, able to identify graft damage with no invasion. Urinary sediment contains cells originating in the kidney parenchyma and infiltrating leukocytes. Higher proinflammatory cytokine levels in urine were observed in patients with acute rejection, nevertheless as single biomarkers, they do not provide enough sensitivity and specificity. A platform combining analysis of microRNAs, a group of short non-coding RNA sequences with regulatory activity, and cytokines in urine was presented by Gielis (Gielis et al. 2021). Proposed combined assay reached $89 \%$ sensitivity and $76 \%$ specificity for rejection.

\section{Conclusion}

ABMR is recognized as a major obstacle to improvement of long-term kidney allograft survival. Up to date diagnosis of ABMR is based on the binary classification, because of which the medical practitioners have to decide whether a patient does or does not have ABMR.

Rejection in clinical practice is a complex process, difficult to simplify into few clearly distinct categories.

ABMR diagnosis is currently based on two main pillars, a histologic assessment and the detection of DSAs, both of which have their limitations. Histologic assessment of biopsy samples offers a low degree of specificity, high interobserver variability and the probability of concomitant inflammation in both microvascular and tubulointerstitial compartments. DSAs are often undetected in cases with histological ABMR.

Research attempts to resolve the limitations of the standard of care are trying to reveal novel pathophysiological mechanisms underlying these ambiguous cases. Non-HLA antibody evaluation is still not a standardized process, and their independent pathological and prognostic meaning is uncertain. Antibody independent NK cell activation reflecting killer-cells inhibitory receptor incompatibility is suggested in microvascular inflammation in DSA negative patients. Transcriptomic research offers new insights into graft pathology on the cellular level. The 
first commercially available tool for assessment of graft biopsies with the microarray technology is at a disposal, and some clinical trials had adopted results from the MMDx as a secondary endpoint. Novel non-invasive biomarkers based on the presence of donor genetic information or immune system regulatory molecules in the recipient's bloodstream or urine have a potential to serve as an early alert for clinicians to look for possible threats for the allograft.

\section{Conflict of Interest}

There is no conflict of interest.

\section{Acknowledgements}

Supported by the Ministry of Health of the Czech Republic MZO 00023001 and by the Ministry of Health of the Czech Republic under grants NV19-06-00031 and NU21-06-00021.

\section{References}

AMROUCHE L, AUBERT O, SUBERBIELLE C, RABANT M, VAN HUYEN JD, MARTINEZ F, SBERROSOUSSAN R, SCEMLA A, TINEL C, SNANOUDJ R, ZUBER J, CAVALCANTI R, TIMSIT MO, LAMHAUT L, ANGLICHEAU D, LOUPY A, LEGENDRE C: Long-term Outcomes of Kidney Transplantation in Patients With High Levels of Preformed DSA: The Necker High-Risk Transplant Program. Transplantation 101: 2440-2448, 2017. https://doi.org/10.1097/TP.0000000000001650

ANAND S, LOPEZ-VERDUGO F, SANCHEZ-GARCIA J, DONG L, FIFE M, KRONG J, MORRIS D, SRINIVAS TR: Longitudinal variance of Donor-Derived Cell-Free DNA (dd-cfDNA) in Stable Kidney Transplant (KTx) patients are influenced by donor/recipient variables. Clin Transplant online ahead of print, 2021. https://doi.org/10.1111/ctr.14395

BRAY RA, TARSITANI C, GEBEL HM, LEE JH: Clinical cytometry and progress in HLA antibody detection. Methods Cell Biol 103: 285-310, 2011. https://doi.org/10.1016/B978-0-12-385493-3.00012-7

BUELOW R, MERCIER I, GLANVILLE L, REGAN J, ELLINGSON L, JANDA G, CLAAS F, COLOMBE B, GELDER F, GROSSE-WILDE H: Detection of panel-reactive anti-HLA class I antibodies by enzyme-linked immunosorbent assay or lymphocytotoxicity. Results of a blinded, controlled multicenter study. Hum Immunol 44: 1-11, 1995. https://doi.org/10.1016/0198-8859(95)00057-B

CALLEMEYN J, LERUT E, DE LOOR H, ARIJS I, THAUNAT O, KOENIG A, MEAS-YEDID V, OLIVO-MARIN JC, HALLORAN P, CHANG J, THORREZ L, KUYPERS D, SPRANGERS B, VAN LOMMEL L, SCHUIT F, ESSIG M, GWINNER W, ANGLICHEAU D, MARQUET P, NAESENS M: Transcriptional changes in kidney allografts with histology of antibody-mediated rejection without anti-HLA donor-specific antibodies. J Am Soc Nephrol 31: 2168-2183, 2020. https://doi.org/10.1681/ASN.2020030306

CHARREAU B: Cellular and molecular crosstalk of graft endothelial cells during amr: effector functions and mechanisms. Transplantation online ahead of print, 2021. https://doi.org/10.1097/TP.0000000000003741

DELVILlE M, LAMARTHÉE B, PAGIE S, SEE SB, RABANT M, BURGER C, GATAULT P, GIRAL M, THAUNAT O, ARZOUK N, HERTIG A, HAZZAN M, MATIGNON M, MARIAT C, CAILLARD S, KAMAR N, SAYEGH J, WESTEEL PF, GARROUSTE C, LADRIÈRE M, VUIBLET V, RIVALAN J, MERVILLE P, BERTRAND D, LE MOINE A, DUONG VAN HUYEN JP, CESBRON A, CAGNARD N, ALIBEU O, SATCHELL SC, LEGENDRE C, ZORN E, TAUPIN JL, CHARREAU B, ANGLICHEAU D: Early acute microvascular kidney transplant rejection in the absence of anti-HLA antibodies is associated with preformed IgG antibodies against diverse glomerular endothelial cell antigens. J Am Soc Nephrol 30: 692-709, 2019. https://doi.org/10.1681/ASN.2018080868

DE MENEZES NEVES PD, MACHADO JR, DOS REIS MA, FALEIROS AC, DE LIMA PEREIRA SA, RODRIGUES DB: Distinct expression of interleukin 17, tumor necrosis factor $\alpha$, transforming growth factor $\beta$, and forkhead box P3 in acute rejection after kidney transplantation. Ann Diagn Pathol 17: 75-79, 2013. https://doi.org/10.1016/j.anndiagpath.2012.08.002

DE SOUZA L, PRUNSTER J, CHAN D, CHAKERA A, LIM WH: Recurrent glomerulonephritis after kidney transplantation: a practical approach. Curr Opin Organ Transplant 26: 360-380, 2021. https://doi.org/10.1097/MOT.0000000000000887 
DJAMALI A, KAUFMAN DB, ELLIS TM, ZHONG W, MATAS A, SAMANIEGO M: Diagnosis and management of antibody-mediated rejection: current status and novel approaches. Am J Transplant 14: 255-271, 2014. https://doi.org/10.1111/ajt.12589

DOMINY KM, WILLICOMBE M, AL JOHANI T, BECKWITH H, GOODALL D, BROOKES P, COOK HT, CAIRNS T, MCLEAN A, ROUFOSSE C: Molecular assessment of C4d-positive renal transplant biopsies without evidence of rejection. Kidney Int Rep 4: 148-158, 2018. https://doi.org/10.1016/j.ekir.2018.09.005

DRAGUN D, MÜLLER DN, BRÄSEN JH, FRITSCHE L, NIEMINEN-KELHÄ M, DECHEND R, KINTSCHER U, RUDOLPH B, HOEBEKE J, ECKERT D, MAZAK I, PLEHM R, SCHÖNEMANN C, UNGER T, BUDDE K, NEUMAYER HH, LUFT FC, WALLUKAT G: Angiotensin II type 1-receptor activating antibodies in renal-allograft rejection. N Engl J Med 352: 558-569, 2005. https://doi.org/10.1056/NEJMoa035717

FICHTNER A, SÜSAL C, HÖCKER B, RIEGER S, WALDHERR R, WESTHOFF JH, SANDER A, DRAGUN D, TÖNSHOFF B: Association of non-HLA antibodies against endothelial targets and donor-specific HLA antibodies with antibody-mediated rejection and graft function in pediatric kidney transplant recipients. Pediatr Nephrol 36: 2473-2484, 2021. https://doi.org/10.1007/s00467-021-04969-1

GARG N, SAMANIEGO MD, CLARK D, DJAMALI A: Defining the phenotype of antibody-mediated rejection in kidney transplantation: Advances in diagnosis of antibody injury. Transplant Rev (Orlando) 31: 257-267, 2017. https://doi.org/10.1016/j.trre.2017.08.005

GIELIS EM, ANHOLTS JDH, VAN BEELEN E, HAASNOOT GW, DE FIJTER HW, BAJEMA I, HEIDT S, VAN DE VRIE M, HILBRANDS LB, MALLAT MJK, LEDEGANCK KJ, CLAAS FHJ, EIKMANS M: A combined microRNA and chemokine profile in urine to identify rejection after kidney transplantation. Transplant Direct 7: e711, 2021. https://doi.org/10.1097/TXD.0000000000001169

GOPLANI KR, VANIKAR AV, SHAH PR, GUMBER M, FEROZ A, PATEL HV, KASAT P, FALODIA J, SABOO D, KASWAAN K, GEERISH MS, PANDYA T, TRIVEDI HL: Postrenal transplant hemolytic uremic syndrome/thrombotic microangiopathy: Ahmedabad experience. Transplant Proc 40: 1114-1116, 2008. https://doi.org/10.1016/j.transproceed.2008.03.028

GOYTAIN A, NG T: NanoString nCounter Technology: High-Throughput RNA Validation. Methods Mol Biol 2079: 125-139, 2020. https://doi.org/10.1007/978-1-4939-9904-0 10

GUPTA G, MOINUDDIN I, KAMAL L, KING AL, WINSTEAD R, DEMEHIN M, KANG L, KIMBALL P, LEVY M, BHATI C, MASSEY HD, KUMAR D, HALLORAN PF: Correlation of Donor-Derived Cell-free DNA with Histology and Molecular Diagnoses of Kidney Transplant Biopsies. Transplantation online ahead of print, 2021. https://doi.org/10.1097/TP.0000000000003838

HAAS M, LOUPY A, LEFAUCHEUR C, ROUFOSSE C, GLOTZ D, SERON D, NANKIVELL BJ, HALLORAN PF, COLVIN RB, AKALIN E, ALACHKAR N, BAGNASCO S, BOUATOU Y, BECKER JU, CORNELL LD, DUONG VAN HUYEN JP, GIBSON IW, KRAUS ES, MANNON RB, NAESENS M, NICKELEIT V, NICKERSON P, SEGEV DL, SINGH HK, STEGALL M, RANDHAWA P, RACUSEN L, SOLEZ K, MENGEL M: The Banff 2017 Kidney Meeting Report: Revised diagnostic criteria for chronic active $\mathrm{T}$ cell-mediated rejection, antibody-mediated rejection, and prospects for integrative endpoints for next-generation clinical trials. Am J Transplant 18: 293-307, 2018. https://doi.org/10.1111/ajt.14625

HAAS M, SIS B, RACUSEN LC, SOLEZ K, GLOTZ D, COLVIN RB, CASTRO MC, DAVID DS, DAVID-NETO E, BAGNASCO SM, CENDALES LC, CORNELL LD, DEMETRIS AJ, DRACHENBERG CB, FARVER CF, FARRIS AB 3RD, GIBSON IW, KRAUS E, LIAPIS H, LOUPY A, NICKELEIT V, RANDHAWA P, RODRIGUEZ ER, RUSH D, SMITH RN, TAN CD, WALLACE WD, MENGEL M: Banff meeting report writing committee. Banff 2013 meeting report: inclusion of c4d-negative antibody-mediated rejection and antibody-associated arterial lesions. Am J Transplant 14: 272-83, 2014. https://doi.org/10.1111/ajt.12590

HARA S: Cell mediated rejection revisited: Past, current, and future directions. Nephrology (Carlton) 23 Suppl 2: 45-51, 2018. https://doi.org/10.1111/nep.13283

HALLORAN PF, PEREIRA AB, CHANG J, MATAS A, PICTON M, DE FREITAS D, BROMBERG J, SERÓN D, SELLARÉS J, EINECKE G, REEVE J: Microarray diagnosis of antibody-mediated rejection in kidney transplant biopsies: an international prospective study (INTERCOM). Am J Transplant 13: 2865-2874, 2013. https://doi.org/10.1111/ajt.12465 
HALLORAN PF, REEVE J, AKALIN E, AUBERT O, BOHMIG GA, BRENNAN D, BROMBERG J, EINECKE G, ESKANDARY F, GOSSET C, DUONG VAN HUYEN JP, GUPTA G, LEFAUCHEUR C, MALONE A, MANNON RB, SERON D, SELLARES J, WEIR M, LOUPY A: Real Time Central Assessment of Kidney Transplant Indication Biopsies by Microarrays: The INTERCOMEX Study. Am J Transplant 17: 2851-2862, 2017. https://doi.org/10.1111/ajt.14329

HEIDT S, HAASNOOT GW, CLAAS FHJ: How the definition of acceptable antigens and epitope analysis can facilitate transplantation of highly sensitized patients with excellent long-term graft survival. Curr Opin Organ Transplant 23: 493-499, 2018. https://doi.org/10.1097/MOT.0000000000000545

HRUBA P, KREJCIK Z, STRANECKY V, MALUSKOVA J, SLATINSKA J, GUELER F, GWINNER W, BRÄSEN JH, WOHLFAHRTOVA M, PARIKOVA A, OSICKOVA K, FRONEK J, SEDA O, PREFERTUSOVA L, HONSOVA E, VIKLICKY O: Molecular Patterns Discriminate Accommodation and Subclinical Antibodymediated Rejection in Kidney Transplantation. Transplantation 103: 909-917, 2019. https://doi.org/10.1097/TP.0000000000002604

KOENIG A, CHEN CC, MARÇAIS A, BARBA T, MATHIAS V, SICARD A, RABEYRIN M, RACAPÉ M, DUONG-VAN-HUYEN JP, BRUNEVAL P, LOUPY A, DUSSURGEY S, DUCREUX S, MEAS-YEDID V, OLIVO-MARIN JC, PAIDASSI H, GUILLEMAIN R, TAUPIN JL, CALLEMEYN J, MORELON E, NICOLETTI A, CHARREAU B, DUBOIS V, NAESENS M, WALZER T, DEFRANCE T, THAUNAT O: Missing self triggers NK cell-mediated chronic vascular rejection of solid organ transplants. Nat Commun 10 : 5350, 2019. https://doi.org/10.1038/s41467-019-13113-5

KOENIG A, MEZAACHE S, CALLEMEYN J, BARBA T, MATHIAS V, SICARD A, CHARREAU B, RABEYRIN M, DIJOUD F, PICARD C, MEAS-YEDID V, OLIVO-MARIN JC, MORELON E, NAESENS M, DUBOIS V, THAUNAT O: Missing self-induced activation of nk cells combines with non-complement-fixing donorspecific antibodies to accelerate kidney transplant loss in chronic antibody-mediated rejection. J Am Soc Nephrol 32: 479-494, 2021. https://doi.org/10.1681/ASN.2020040433

KRAMER A, BOENINK R, STEL VS, SANTIUSTE DE PABLOS C, TOMOVIĆ F, GOLAN E, KERSCHBAUM J, SEYAHI N, IOANOU K, BELTRÁN P, ZURRIAGA O, MAGAZ Á, SLON ROBLERO MF, GJORGJIEVSKI N, GARNEATA L, ARRIBAS F, GALVÃO AA, BELL S, OTS-ROSENBERG M, MUÑOZ-TEROL JM, WINZELER R, HOMMEL K, ÅSBERG A, SPUSTOVA V, PALENCIA GARCÍA MÁ, VAZELOV E, FINNE P, TEN DAM MAGJ, LOPOT F, TRUJILLO-ALEMÁN S, LASSALLE M, KOLESNYK MO, SANTHAKUMARAN S, IDRIZI A, ANDRUSEV A, COMAS FARNÉS J, KOMISSAROV K, RESIĆ H, PALSSON R, KUZEMA V, GARCIA BAZAGA MA, ZIGINSKIENE E, STENDAHL M, BONTHUIS M, MASSY ZA, JAGER KJ: The ERA-EDTA Registry Annual Report 2018: A summary. Clin Kidney J 14: 107-123, 2020. https://doi.org/10.1093/ckj/sfaa271

LECHEVALLIER E, DUSSOL B, LUCCIONI A, THIRION X, VACHER-COPOMAT H, JABER K, BRUNET P, LEONETTI F, LAVELLE O, COULANGE C, BERLAND Y: Posttransplantation acute tubular necrosis: risk factors and implications for graft survival. Am J Kidney Dis 32:984-991, 1998. https://doi.org/10.1016/S0272$\underline{6386(98) 70073-3}$

LEFAUCHEUR C, LOUPY A, VERNEREY D, DUONG-VAN-HUYEN JP, SUBERBIELLE C, ANGLICHEAU D, VÉRINE J, BEUSCART T, NOCHY D, BRUNEVAL P, CHARRON D, DELAHOUSSE M, EMPANA JP, HILL GS, GLOTZ D, LEGENDRE C, JOUVEN X: Antibody-mediated vascular rejection of kidney allografts: a population-based study. Lancet 381: 313-319, 2013. https://doi.org/10.1016/S0140-6736(12)61265-3

LEFAUCHEUR C, VIGLIETTI D, BOUATOU Y, PHILIPPE A, PIEVANI D, AUBERT O, DUONG VAN HUYEN JP, TAUPIN JL, GLOTZ D, LEGENDRE C, LOUPY A, HALLORAN PF, DRAGUN D: Non-HLA agonistic anti-angiotensin II type 1 receptor antibodies induce a distinctive phenotype of antibody-mediated rejection in kidney transplant recipients. Kidney Int 96: 189-201, 2019. https://doi.org/10.1016/j.kint.2019.01.030

LIPMAN ML, STEVENS AC, BLEACKLEY RC, HELDERMAN JH, MCCUNE TR, HARMON WE, SHAPIRO ME, ROSEN S, STROM TB: The strong correlation of cytotoxic T lymphocyte-specific serine protease gene transcripts with renal allograft rejection. Transplantation 53: 73-79, 1992. https://doi.org/10.1097/00007890199201000-00014 
LOUPY A, HAAS M, ROUFOSSE C, NAESENS M, ADAM B, AFROUZIAN M, AKALIN E, ALACHKAR N, BAGNASCO S, BECKER JU, CORNELL LD, CLAHSEN-VAN GRONINGEN MC, DEMETRIS AJ, DRAGUN D, DUONG VAN HUYEN JP, FARRIS AB, FOGO AB, GIBSON IW, GLOTZ D, GUEGUEN J, KIKIC Z, KOZAKOWSKI N, KRAUS E, LEFAUCHEUR C, LIAPIS H, MANNON RB, MONTGOMERY RA, NANKIVELL BJ, NICKELEIT V, NICKERSON P, RABANT M, RACUSEN L, RANDHAWA P, ROBIN B, ROSALES IA, SAPIR-PICHHADZE R, SCHINSTOCK CA, SERON D, SINGH HK, SMITH RN, STEGALL MD, ZEEVI A, SOLEZ K, COLVIN RB, MENGEL M: The Banff 2019 Kidney Meeting Report (I): Updates on and clarification of criteria for T cell- and antibody-mediated rejection. Am J Transplant 20: 2318-2331, 2020. https://doi.org/10.1111/ajt.15898

LOUPY A, HAAS M, SOLEZ K, RACUSEN L, GLOTZ D, SERON D, NANKIVELL BJ, COLVIN RB, AFROUZIAN M, AKALIN E, ALACHKAR N, BAGNASCO S, BECKER JU, CORNELL L, DRACHENBERG C, DRAGUN D, DE KORT H, GIBSON IW, KRAUS ES, LEFAUCHEUR C, LEGENDRE C, LIAPIS H, MUTHUKUMAR T, NICKELEIT V, ORANDI B, PARK W, RABANT M, RANDHAWA P, REED EF, ROUFOSSE C, SESHAN SV, SIS B, SINGH HK, SCHINSTOCK C, TAMBUR A, ZEEVI A, MENGEL M: The Banff 2015 Kidney Meeting Report: Current Challenges in Rejection Classification and Prospects for Adopting Molecular Pathology. Am J Transplant 17: 28-41, 2017. https://doi.org/10.1111/ajt.14107

LOUPY A, LEFAUCHEUR C, VERNEREY D, PRUGGER C, DUONG VAN HUYEN JP, MOONEY N, SUBERBIELLE C, FRÉMEAUX-BACCHI V, MÉJEAN A, DESGRANDCHAMPS F, ANGLICHEAU D, NOCHY D, CHARRON D, EMPANA JP, DELAHOUSSE M, LEGENDRE C, GLOTZ D, HILL GS, ZEEVI A, JOUVEN X: Complement-binding anti-HLA antibodies and kidney-allograft survival. N Engl J Med 369: 1215-1226, 2013. https://doi.org/10.1056/NEJMoa1302506

LUQUE S, LÚCIA M, MELILLI E, LEFAUCHEUR C, CRESPO M, LOUPY A, BERNAL-CASAS D, GOMÀ M, JARQUE M, CRESPO E, MONTERO N, MANONELLES A, CRUZADO JM, GIL-VERNET S, GRINYÓ JM, BESTARD O: Value of monitoring circulating donor-reactive memory B cells to characterize antibodymediated rejection after kidney transplantation. Am J Transplant 19: 368-380, 2019. https://doi.org/10.1111/ajt.15055

MADILL-THOMSEN KS, PERKOWSKA-PTASIŃSKA A, BÖHMIG GA, ESKANDARY F, EINECKE G, GUPTA G, HALLORAN PF: MMDx-Kidney Study Group. Discrepancy analysis comparing molecular and histology diagnoses in kidney transplant biopsies. Am J Transplant 20: 1341-1350, 2020. https://doi.org/10.1111/ajt.15752

MADILL-THOMSEN KS, WIGGINS RC, ESKANDARY F, BÖHMIG GA, HALLORAN PF: The Effect of Cortex/Medulla Proportions on Molecular Diagnoses in Kidney Transplant Biopsies: Rejection and Injury Can Be Assessed in Medulla. Am J Transplant 17: 2117-2128, 2017. https://doi.org/10.1111/ajt.14233

MAUIYYEDI S, CRESPO M, COLLINS AB, SCHNEEBERGER EE, PASCUAL MA, SAIDMAN SL, TOLKOFFRUBIN NE, WILLIAMS WW, DELMONICO FL, COSIMI AB, COLVIN RB: Acute humoral rejection in kidney transplantation: II. Morphology, immunopathology, and pathologic classification. J Am Soc Nephrol 13: 779-787, 2002. https://doi.org/10.1681/ASN.V133779

MENGEL M, LOUPY A, HAAS M, ROUFOSSE C, NAESENS M, AKALIN E, CLAHSEN-VAN GRONINGEN MC, DAGOBERT J, DEMETRIS AJ, DUONG VAN HUYEN JP, GUEGUEN J, ISSA F, ROBIN B, ROSALES I, VON DER THÜSEN JH, SANCHEZ-FUEYO A, SMITH RN, WOOD K, ADAM B, COLVIN RB: Banff 2019 Meeting Report: Molecular diagnostics in solid organ transplantation-Consensus for the Banff Human Organ Transplant (B-HOT) gene panel and open source multicenter validation. Am J Transplant 20: 2305-2317, 2020. https://doi.org/10.1111/ajt.16059

MENGEL M, SIS B, HAAS M, COLVIN RB, HALLORAN PF, RACUSEN LC, SOLEZ K, CENDALES L, DEMETRIS AJ, DRACHENBERG CB, FARVER CF, RODRIGUEZ ER, WALLACE WD, GLOTZ D: Banff meeting report writing committee. Banff 2011 Meeting report: new concepts in antibody-mediated rejection. Am J Transplant 12: 563-570, 2012. https://doi.org/10.1111/j.1600-6143.2011.03926.x 
MOHAMMED MT, CAI S, HANSON BL, ZHANG H, CLEMENT RL, DACCACHE J, CAVAZZONI CB, BLAZAR BR, ALESSANDRINI A, RENNKE HG, CHANDRAKER A, SAGE PT: Follicular T cells mediate donorspecific antibody and rejection after solid organ transplantation. Am J Transplant 21: 1893-1901, 2021. https://doi.org/10.1111/ajt.16484

MORETTA A, BOTTINO C, PENDE D, TRIPODI G, TAMBUSSI G, VIALE O, ORENGO A, BARBARESI M, MERLI A, CICCONE E: Identification of four subsets of human CD3-CD16+ natural killer (NK) cells by the expression of clonally distributed functional surface molecules: correlation between subset assignment of NK clones and ability to mediate specific alloantigen recognition. J Exp Med 172: 1589-98, 1990. https://doi.org/10.1084/jem.172.6.1589

MUMFORD L, FUGGLE SV, MARTORELL J, SLAVCEV A, INIOTAKI A, HAASNOOT GW, HEIDT S, CLAAS FHJ: A Europe wide acceptable mismatch program will enable transplantation of long waiting highly sensitised patients with a compatible donor. Transpl Immunol 64: 101354, 2021. https://doi.org/10.1016/j.trim.2020.101354

NELSON PW, ESCHLIMAN P, SHIELD CF, AEDER MI, LUGER AM, PIERCE GE, BRYAN CF: Improved graft survival in cadaveric renal retransplantation by flow crossmatching. Arch Surg 131: 599-603, 1996. https://doi.org/10.1001/archsurg.1996.01430180025004

NOVOTNY M, HRUBA P, VICHOVA P, MALUSKOVA J, HONSOVA E, VIKLICKY O, WOHLFAHRTOVA M: Isolated v-lesion represents a benign phenotype of vascular rejection of the kidney allograft - a retrospective study. Transpl Int 31: 1153-1163, 2018. https://doi.org/10.1111/tri.13286

OHLÉN C, KLING G, HÖGLUND P, HANSSON M, SCANGOS G, BIEBERICH C, JAY G, KÄRRE K: Prevention of allogeneic bone marrow graft rejection by H-2 transgene in donor mice. Science 246: 666-8, 1989. https://doi.org/10.1126/science.2814488

PARAJULI S, AZIZ F, GARG N, PANZER SE, JOACHIM E, MUTH B, MOHAMED M, BLAZEL J, ZHONG W, ASTOR BC, MANDELBROT DA, DJAMALI A: Histopathological characteristics and causes of kidney graft failure in the current era of immunosuppression. World $J$ Transplant 9: 123-133, 2019. https://doi.org/10.5500/wjt.v9.i6.123

PERNIN V, BEYZE A, SZWARC I, BEC N, SALSAC C, PEREZ-GARCIA E, MOURAD G, MERVILLE P, VISENTIN J, PERROCHIA H, LARROQUE C, COUZI L, LE QUINTREC M: Distribution of de novo donorspecific antibody subclasses quantified by mass spectrometry: high IgG3 proportion is associated with antibody-mediated rejection occurrence and severity. Front Immunol 11: 919, 2020. https://doi.org/10.3389/fimmu.2020.00919

RACUSEN LC, COLVIN RB, SOLEZ K, MIHATSCH MJ, HALLORAN PF, CAMPBELL PM, CECKA MJ, COSYNS JP, DEMETRIS AJ, FISHBEIN MC, FOGO A, FURNESS P, GIBSON IW, GLOTZ D, HAYRY P, HUNSICKERN L, KASHGARIAN M, KERMAN R, MAGIL AJ, MONTGOMERY R, MOROZUMI K, NICKELEIT V, RANDHAWA P, REGELE H, SERON D, SESHAN S, SUND S, TRPKOV K: Antibodymediated rejection criteria - an addition to the Banff 97 classification of renal allograft rejection. Am J Transplant 3: 708-14, 2003. https://doi.org/10.1034/j.1600-6143.2003.00072.x

REGELE H, EXNER M, WATSCHINGER B, WENTER C, WAHRMANN M, OSTERREICHER C, SÄEMANN MD, MERSICH N, HÖRL WH, ZLABINGER GJ, BÖHMIG GA: Endothelial C4d deposition is associated with inferior kidney allograft outcome independently of cellular rejection. Nephrol Dial Transplant 16: 2058-66, 2001. https://doi.org/10.1093/ndt/16.10.2058

REINDL-SCHWAIGHOFER R, HEINZEL A, KAINZ A, VAN SETTEN J, JELENCSICS K, HU K, LOZA BL, KAMMER M, HEINZE G, HRUBA P, KONARIKOVA A, VIKLICKY O, BOEHMIG GA, ESKANDARY F, FISCHER G, CLAAS F, TAN JC, ALBERT TJ, PATEL J, KEATING B, OBERBAUER R: iGeneTRAiN consortium. Contribution of non-HLA incompatibility between donor and recipient to kidney allograft survival: genome-wide analysis in a prospective cohort. Lancet 393: 910-917, 2019. https://doi.org/10.1016/S0140-6736(18)32473-5

REMUZZI G, BERTANI T: Renal vascular and thrombotic effects of cyclosporine. Am J Kidney Dis 13: 261-272, 1989. https://doi.org/10.1016/S0272-6386(89)80032-0 
SCHINSTOCK CA, ASKAR M, BAGNASCO SM, BATAL I, BOW L, BUDDE K, CAMPBELL P, CARROLL R, CLAHSEN-VAN GRONINGEN MC, COOPER M, CORNELL LD, COZZI E, DADHANIA D, DIEKMANN F, HESSELINK DA, JACKSON AM, KIKIC Z, LOWER F, NAESENS M, ROELOFS JJ, SAPIRPICHHADZE R, KRAUS ES: A 2020 Banff Antibody-mediated Injury Working Group examination of international practices for diagnosing antibody-mediated rejection in kidney transplantation - a cohort study. Transpl Int 34: 488-498, 2021. https://doi.org/10.1111/tri.13813

SENEV A, COEMANS M, LERUT E, VAN SANDT V, DANIËLS L, KUYPERS D, SPRANGERS B, EMONDS MP, NAESENS M: Histological picture of antibody-mediated rejection without donor-specific anti-HLA antibodies: Clinical presentation and implications for outcome. Am J Transplant 19: 763-780, 2019. https://doi.org/10.1111/ajt.15074

SOLEZ K, AXELSEN RA, BENEDIKTSSON H, BURDICK JF, COHEN AH, COLVIN RB, CROKER BP, DROZ D, DUNNILL MS, HALLORAN PF: International standardization of criteria for the histologic diagnosis of renal allograft rejection: the Banff working classification of kidney transplant pathology. Kidney Int 44: 411-422, 1993. https://doi.org/10.1038/ki.1993.259

WOHLFAHRTOVA M, HRUBA P, KLEMA J, NOVOTNY M, KREJCIK Z, STRANECKY V, HONSOVA E, VICHOVA P, VIKLICKY O: Early isolated V-lesion may not truly represent rejection of the kidney allograft. Clin Sci (Lond) 132: 2269-2284, 2018. https://doi.org/10.1042/CS20180745

ZHANG R: Donor-Specific Antibodies in Kidney Transplant Recipients. Clin J Am Soc Nephrol 13: 182-192, 2018. https://doi.org/10.2215/CJN.00700117 